\title{
ANALISIS NETWORK MONITORING SYSTEM DENGAN MENGGUNAKAN PROBE
}

\author{
Fitria Nova Hulu ${ }^{1}$ \\ Pipi Andini ${ }^{2}$
}

\begin{abstract}
Network monitoring system is necessary in maintaining the quality of performance of a customer service provider. PROBE is a network monitoring system that is very necessary in maintaining the quality of performance of a customer service provider. PROBE is a means or application used by one of the telecommunication and network service providers of Huawei. The measurement and observation process using PROBE is done in 2 stages: Mobility and Statistical Process. Both processes will show the signal condition of a transmitting antenna (BTS). PROBE will also show signal quality with six color indicators: dark red, pink, green, yellow, orange and red. The indicator will be compared to the signal quality level received by the user against the frequency generated from the transmitting antenna (RSRP). facilities or applications used by one of the telecommunication and network service providers of Huawei. The measurement and observation process using PROBE is done in 2 stages: Mobility and Statistical Process. Both processes will show the signal condition of a transmitting antenna (BTS). PROBE will also show signal quality with six color indicators: dark red, pink, green, yellow, orange and red. Where each indicator is compared with the signal quality level received by the user against the frequency generated from the transmitting antenna (RSRP).
\end{abstract}

Keywords: Internet, Networking, PROBE

\section{INTI SAR I}

Sistem monitoring jaringan sangat diperlukan dalam menjaga kualitas kinerja sebuah penyedia jasa layanan pelanggan. PROBE merupakan suatu sarana atau aplikasi yang digunakan oleh salah satu perusahaan penyedia layanan telekomunikasi dan jaringan yaitu Huawei. Proses pengukuran dan pengamatan dengan menggunakan PROBE dilakukan dalam 2 tahap yaitu Mobility dan Proses Statistik. Kedua proses tersebut akan memperlihatkan kondisi sinyal sebuah Antena Pemancar (BTS). PROBE juga akan memperlihatkan kualitas sinyal dengan enam indikator warna yaitu : merah tua, merah muda, hijau, kuning, oranye dan merah. Dimana masing-masing indikator dibandingkan dengan tingkat kualitas kekuatan sinyal yang diterima oleh pengguna terhada frekuensi yang dihasilkan dari antena pemancar tersebut (RSRP).

Kata Kunci : Internet, Jaringan, PROBE 


\footnotetext{
${ }^{1}$ Dosen Prodi Teknik Elektro Universitas Pembangunan Panca Budi Medan

${ }^{2}$ Dosen Prodi Teknik Elektro Universitas Pembangunan Panca Budi Medan
}

\section{PENDAHULUAN}

Tidak bisa dipungkiri bahwa teknologi sangat diperlukan dalam pengembangan dan perkembangan dunia komunikasi. Di Indonesia sendiri telah berdiri berbagai macam jasa penyedia layanan informasi pelanggan atau lebih dikenal dengan sebutan provider, seperti : Telkomsel, XL, Indosat, dll. Sebagai salah satu pengguna jasa layanan pelanggan, penulis mencoba untuk melakukan analisa kinerja jaringan internet dengan menggunakan sebuah aplikasi yaitu PROBE.

Komunikasi yang dilakukan saat ini sudah sangat jauh berbeda dibandingkan dengan jaman dulu yang masih menggunakan surat. Para penyedia layanan informasi berlomba-lomba dalam meningkatkan kualitas layanan serta menyediakan berbagai fasilitas agar para pelanggan dapat dengan mudah berkomunikasi hanya dengan menggunakan sebuah perangkat yang dikenal dengan Handphone. Kualitas performa jaringan internet (Optimasi), salah satunya yaitu masalah kecepatan koneksi setiap internet yang dilakukan.

Optimasi adalah proses peningkatan kualitas jaringan seluler agar sesuai denganparameter-parameter kualita jaringan teknologi di operator. Dari optimasi dapat juga diketahui ada tidaknya suatu error atau kerusakan dalam suatu jaringan sistem komunikasi seluler.Dalam jaringan 2G, WCDMA, 3G maupun 4G optimasi sangat diperlukan untuk menjaga kualitas layanan terhadap konsumen agar terjaga dengan baik. Salah satu maintenance dalam optimasi yang dilakukan adalah drive test. [3]

Teknologi memainkan peranan vital dalam meningkatkan kualitas jasa yang dihasilkan oleh suatu perusahaan, salah satu bentuk perkembangan teknologi yang membawa revolusi pada dunia teknologi informasi dan komunikasi (TIK) adalah internet. Revolusi internet merupakan revolusi ketiga di dunia setelah revolusi agraris dan revolusi industry (Khan, et al. 2009).

\section{PENDEKATAN PEMECAHAN MASALAH Jaringan (Network)}

Jaringan komputer adalah sekelompok komputer otonom yang saling berhubungan antara satu dengan lainnya menggunakan protokol komunikasi melalui media komunikasi sehingga dapat saling berbagi informasi, program-program, penggunaan bersama perangkat keras seperti printer, harddisk, dan sebagainya. Selain itu jaringan komputer bisa diartikan sebagai kumpulan sejumlah terminal komunikasi yang berada diberbagai lokasi yang terdiri dari lebih satu komputer yang saling berhubungan. [4]

Jaringan komputer dapat dikelompokkan berdasar luas area yang dapat dijangkau atau dilayani. Secara umum jaringan komputer terbagi menjadi tiga jenis, yaitu Local area network (LAN), Metropolitan area network (MAN), dan Wide area network (WAN). [4]

\section{Perkembangan Generasi Jaringan}

Perkembangan Jaringan mulai dari Generasi pertama (G1) sampai dengan sekarang yaitu generasi keempat (4G) atau sekarang lebih dikenal dengan LTE (Long Term Evolution), bahkan saat ini sudah mulai dikembangkan generasi kelima (5G)hal ini menandakan bahwa perkembangan teknologi dan informasi saat ini sangat vepat. Gambar 1 merupakan ilustrasi perkembangan Gerasi Jaringan muali dari generasi pertema dan seterusnya. [1]

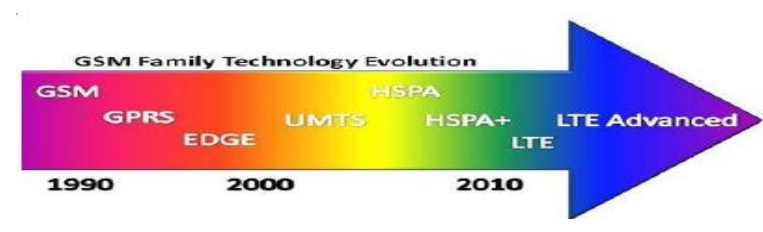

Gambar 1. llustrasi Perkembangan Generasi Jaringan 
Generasi Pertama (1G) : merupakan teknologi handphone pertama yang diperkenalkan pada era 80-an dan masih menggunakan sistem analog dengan teknik komunikasi FDMA.

Generasi Kedua (2G) : muncul karena tuntutan pasar dan kebutuhan akan kualitas yang semakin baik. Generasi 2G sudah menggunakan teknologi digital, dengan teknik komunikasi yang digunakan adalah CDMA ataupun TDMA.

Generasi Ketiga (3G) : standard internasional atau yang lebih dikenal dengan ITU (Intenational Telecomunication Union) mendefisikan 3G (Third Generation) sebagai teknologi yang dapat unjuk kerja yang mempunyai kecepatan transfer data sebesar 144 kbps pada kecepatan user 100 $\mathrm{km} /$ jam. Selain itu $3 \mathrm{G}$ juga mempunyai kecepatan transfer data sebesar 384 kbps pada kecepatan berjalan kaki, serta mempunyai kecepatan transfer data sebesar 2 Mbps pada untuk user diam (stasioner).

Generasi 4 (4G / LTE) : 4G adalah singkatan dari istilah dalam bahasa Inggris: fourth generation technology. Istilah ini umumnya digunakan mengacu kepada pengembangan teknologi telepon seluler, menyediakan solusi IP yang komprehensif dimana suara, data, dan arus multimedia dapat sampai kepada pengguna kapan saja dan dimana saja, pada rata-rata data lebih tinggi dari generasi sebelumnya.. [2]

LTE merupakan nama yang diberikan untuk standar teknologi komunikasi baru yang dikembangkan oleh 3GPP untuk mengatasi peningkatan permintaan kebutuhan akan layanan komunikasi, LTE adalah lanjutan dari evolusi $2 G$ dan $3 G$ sistem dan juga untuk menyediakan layanan tingkat kualitas yang sama dengan jaringan wired.

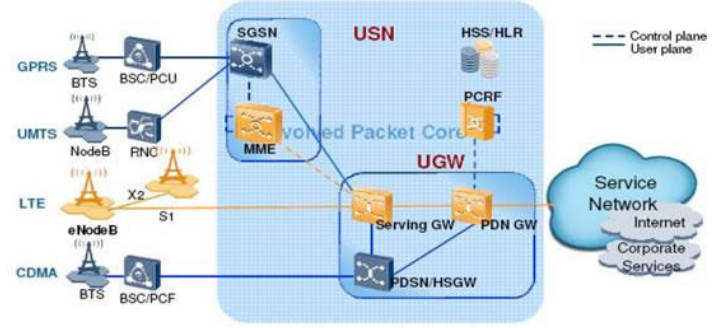

\section{Gambar 2. Arsitektur Jaringan LTE}

\section{HASIL DAN PEMBAHASAN}

\section{Drive Test}

Drive test merupakan salah satu bagian pekerjaan dalam optimasi jaringan radio. Drive test bertujuan untuk mengumpulkan informasi jaringan secara real di lapangan. Informasi yang dikumpulkan merupakan kondisi aktual radio frequency (RF) di suatu eNodeB. [4]
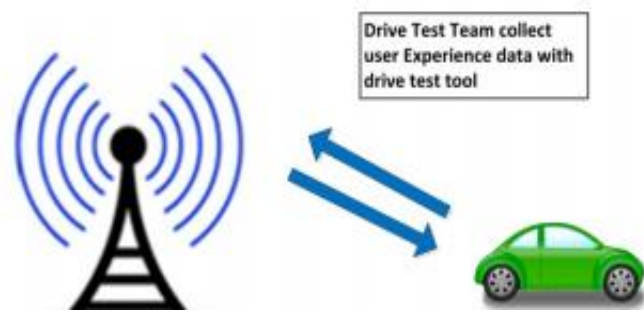

\section{Gambar 3. Pengumpulan Data dengan Aktivitas Drive Test}

Secara umum tujuan kegiatan Drive Test adalah untuk mengumpulkan informasi jaringan frekuensi radio secara real di lapangan. Dimana informasi yang diperoleh dapat digunakan untuk mencapai tujuantujuan berikut ini :

a. Mengetahui coverage sebernarnya di lapangan, apakah sudah sesuai dengan coverage prediction pada saat perencanaan

b. Mengetahui parameter jaringan di lapangan apakah sudah sesuai dengan parameter perencanaan

c. Mengetahui adanya inteferensi dari eNodeB tetangga

d. Mengetahui adanya RF issue, sebagai contoh berkaitan dengan adanya drop call atau blocked call

e. Mengetahui adanya poor coverage

f. Mengetahui performansi jaringan kompetitor (benchmarking). [5]

Sedangkan perangkat yang dibutuhkan dalam menggunakan Drive Test yaitu :

a. Laptop. 
b. Software Drive Test (pada modul ini digunakan Genex Probe)

c. Modem 4G LTE yang berkerja pada frekuensi 900, 1800 dan $2300 \mathrm{MHz}$.

d. LTE SIM Card

e. GPS receiver

f. Peta Maplnfo

g. Data engineer parameter atau Cellfile Data engineer berisi Nama Site, Koordinat (Longitude dan Lititude), $\mathrm{PCl}$, ENodeBID,SectorID, Local ID, Cell ID, Azimuth dan EARFCN. [5]

\section{PROBE}

Hampir sama dengan Drive Test, PROBE juga digunakan untuk mengumpulkan informasi tentang optimasi jaringan internet. Software PROBE biasanya digunakan oleh perusahaan Huawei dimana untuk cara penggunaan serta fungsinya hamper sama dengan yang digunakan oleh perusahaan Ericsson yaitu TEMS.

Ada beberapa langkah dalam mengaktifkan aplikasi PROBE, antara lain :

1. Ekstrak folder Genex Shared dan jalankan file aplikasi setup. Pilih next dengan pilihan default

2. Ekstrak folder Probe-Hard-Version dan jalankan file aplikasi setup. Pilih next dengan pilihan default

3. Apabila genex probe sudah terinstal dengan baik, buka aplikasi genex probe.

Beberapa parameter yang menentukan tingkat kualitas suatu sinyal adalah :

RSRP (Reference Signal Received Power), merupakan kekuatan sinyal yang diterima oleh user dalam frekuensi tertentu. semakin jauh jarak antara site dan user, maka semakin kecil pula RSRP yang diterima oleh user.

RSRQ (Reference Signal Received Quality), merupakan parameter yang menentukan kualitas sinyal yang diterima oleh user.

SINR (Signal to Interference Noise Ratio), merupakan rasio perbandingan antara sinyal utama yang dipancarkan dengan interferensi dan noise yang timbul ( tercampur dengan sinyal utama ) .

CQI (Channel Quality Index), merupakan kualitas dari sebuah channel downlink (dari site ke user) dengan kondisi dedicated mode (pada LTE, user melakukan download data)

PCI (Physical Cell Id), merupakan kode identitas fisik tiap cell.

\section{Analisis Hasil Pengukuran}

Pengukuran dilakukan dengan menggunakan provider $\mathrm{XL}$ dimana hasil uji cluster drive dan kinerja jaringan diperlihatkan pada Tabel 1 berikut ini :

Tabel 1 Informasi Umum Kondisi BTS/Site

\begin{tabular}{|l|l|}
\hline General Site Information & \\
\hline Cluster Name & SP_NCS_4G_B_084_SSO_1 \\
\hline Area & North Sumatra \\
\hline Total number of cluster sites & 1 Site \\
\hline Total number of planned sites & 1 Site \\
\hline Total number of On-AirMacro sites: & 1 Site \\
\hline Total number of Pico Site & 0 Site \\
\hline Total number of pending On-AirMacro Sites & 0 Site \\
\hline Total number of pending On-Air Pico Sites & 0 Site \\
\hline
\end{tabular}

Tabel 1 memperlihatkan kondisi area cakupan yang akan dilakukan drive test jaringan. Dimana kaitan Tabel 1 adalah berupa kegiatan yang akan dilakukan pengukuran, seperti yang terlihat pada Tabel 2 berikut :

Tabel 2. Hasil Pengukuran di BTS/Site

\begin{tabular}{|c|c|c|c|c|c|c|c|c|}
\hline $\begin{array}{l}\mathrm{eNB} \\
\mathrm{ID}\end{array}$ & LTE Site Name & $\begin{array}{c}\text { CellI } \\
\text { D }\end{array}$ & Longitude & | Latitude & $\mathrm{TAC}$ & $\mathrm{PCI}$ & Status & OA Date \\
\hline 220702 & LIE__ENCIRM & 4 & 98.49645 & 356067 & 22005 & 279 & Integrated & 25 sept 17 \\
\hline 220702 & LIE_NENCIRMI & 5 & 98.49645 & 3.50067 & 22005 & 280 & Integrated & 25 sept 17 \\
\hline 220702 & LIE_ERNCIRM! & 6 & 98.49645 & 356067 & 22005 & 281 & Integrated & 25 sept 17 \\
\hline
\end{tabular}

Dari Tabel 2 diketahui bahwa tabel tersebut berisikan nomor area, kode fisik, titik koordinat, nama, dan tanggal pengerjaan dari suatu site, dimana proses pengerjaannya dilakukan dalam 2 kegiatan kegiatan pertama disebut dengan mobility lalu setelah mobility dilakukan statik. Mobility itu ialah suatu kegiatan mengelilingi 
site yg telah dituju hingga ke site tetangga. Dalam mobility dilakukan 2 proses, idle mode dan dedicated mode. Lalu setelah mobility selesai lanjut kepada kegiatan kedua yaitu proses statik, dimana statik itu adalah pengukuran kekuatan sinyal yg dilakukan dengan kegiatan ping, upload download streaming.

Proses Kegiatan pertama (Mobility) terlihat pada Tabel 3 beikut ini :

\section{Tabel 3. Kegiatan Pertama Mobility}

\begin{tabular}{|c|c|c|c|c|c|c|c|}
\hline \multicolumn{2}{|c|}{$\overline{\text { LTE }}$} & \multicolumn{4}{|c|}{ Mobile } & \multirow{2}{*}{ KPI Measured } & \multirow{2}{*}{ Remark } \\
\hline No. & $\overline{\mathrm{UE}}$ & \multicolumn{2}{|c|}{ Method } & RAT & BAND & & \\
\hline \multirow{2}{*}{$\begin{array}{c}\text { Round } \\
1\end{array}$} & Handsetl & Idle & Lock LTE & LTE & 1800 & $\begin{array}{l}\text { RSRP, RSRQ, } \\
\text { PCI Plot }\end{array}$ & \multirow{2}{*}{$\begin{array}{l}1 \text { laptop, separated } \\
\text { round between UL } \\
\& \text { DL Test to } \\
\text { guarantee single } \\
\text { user }\end{array}$} \\
\hline & $\begin{array}{l}\text { HUAWEI } \\
\text { E392 } \\
\text { (Modem) }\end{array}$ & $\begin{array}{l}\text { Dedicated, } \\
\text { continues } \\
\text { download }\end{array}$ & Lock LTE & LTE & 1800 & $\begin{array}{c}\text { PDCP DL THP, } \\
\text { SINR }\end{array}$ & \\
\hline \multirow{2}{*}{$\begin{array}{c}\text { Round } \\
2\end{array}$} & $\begin{array}{l}\text { HUAWEI } \\
\text { E392 } \\
\text { (Modem) }\end{array}$ & $\begin{array}{l}\text { Dedicated, } \\
\text { continues } \\
\text { Upload }\end{array}$ & Lock LTE & LTE & 1800 & PDCP UL THP & \multirow{2}{*}{$\begin{array}{l}1 \text { laptop, separated } \\
\text { round between UL } \\
\text { \& DL Test to } \\
\text { guarantee single } \\
\text { user }\end{array}$} \\
\hline & Handset 1 & $\begin{array}{l}\text { Dedicated, } \\
\text { continues } \\
\text { download }\end{array}$ & $\begin{array}{l}\text { Automatic } \\
\text { (Unlocked) }\end{array}$ & $\begin{array}{c}\text { WCDMA } \\
/ \text { LTE }\end{array}$ & $\begin{array}{c}18002 \\
100\end{array}$ & $\begin{array}{l}\text { IRAT HO on } \\
\text { edge } 4 \mathrm{G} \\
\text { coverage }\end{array}$ & \\
\hline
\end{tabular}

Dari Tabel 3 diketahui bahwa berisikan informasi saat mobiliti melakukan dua kali putaran dalam pengambilan datanya, dimana Putaran pertama menggunakan MS dengan posisi idle, LTE dalam kondisi lock dengan bandwith 1800 dan parameter yang ditentukan yaitu mencari SRP, RSRQ dan PCl Plotnya. Sedangkan modemnya dalam posisi dedicated yaitu sedang melakukan proses download.

Pada putaran kedua, modem dalam posisi dedicated namun kondisi saat ini yaitu sedang melakukan upload, LTE dalam kondisi lock dengan posisi bandwith 1800 . Sedangkan MS nya dalam posisi dedicated sedang melakukan download, automatis berarti bisa berpindah ke $3 \mathrm{G}$ atau $4 \mathrm{G}$.

\subsection{Informasi Peta}

Uji coba pengukuran site dilakukan dengna menyesuaikan keadaan lokasi erdasarkan peta. Gambar 4 berikut merupakan tampilan peta lokasi dengan memanfaatkan google earth.

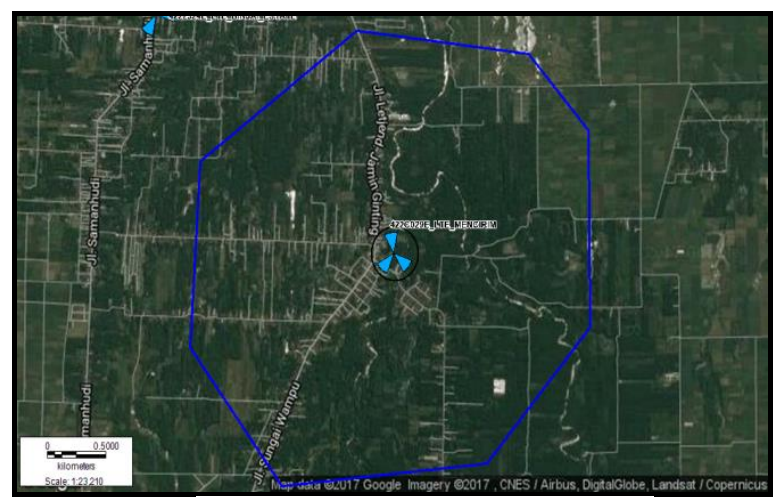

Gambar 4, Tampilan Peta berdasarkan Google Earth

Gambar 4 memperlihatkan lebar cakupan area saat dilakukan pengukuran. Indikasi warna viru ditengah merupakan tampilan site/bts saat sedang dilakukan pengukuran dengan menggunakan PROBE.

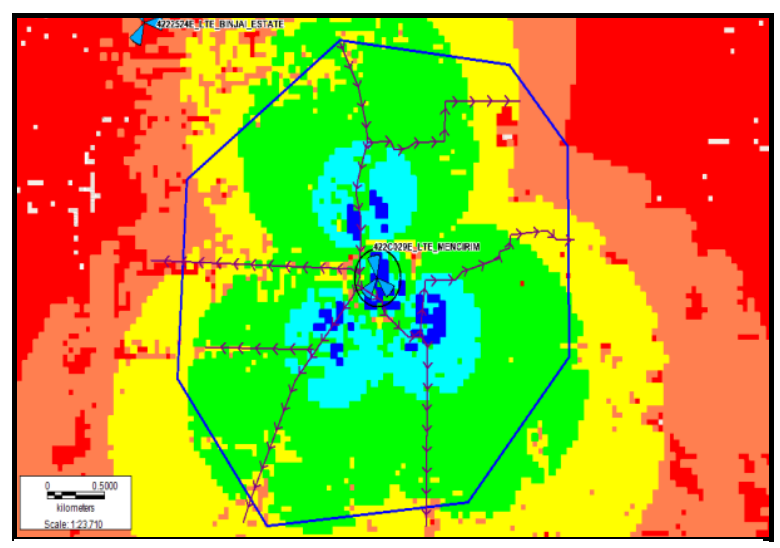

Gambar 5. Prediksi cakupan area dengan mengguankan PROBE

Dari Gambar 5 diketahui bahwa terdapat beberapa indikator-indikator warna yang menerangkan lebar cakupan jaringan transmisi antena bts/site terhadap kualitas kinerja providenya.

Adapun arti dari setiap indikator adalah sebagai berikut :

Indikator Biru Tua : tepat ditengah-tengah site cluster menandakan kondisi pemancar dari antenna bts dengan kualitas koneksi jaringan Sangat Baik.

Indkikator Biru Muda : juga memperlihatkan kondisi area cakupan sinyal dengan tingkat koneksi yang Baik 
Indikator Hijau : merupakan indikator untuk mengetahui bahwa kualitas kinerja jaringan yang dipancarkan oleh antenna bts dalam kondisi sangat baik, karena masih berada sangat dekat dan memang masih termasuk ke dalam lebar band frekuensi antenna pemancar bts tersebut, sehingga pengguna jasa di wilayah dengan indikator hijau mendapatkan kualitas sinyal yang Cukup Baik.

Indikator Kuning : merupakan wilayah yang hampir tidak mendapatkan kualitas sinyal yang baik, di indikator ini pengguna jasa layanan tetap masih bisa menggunakan koneksi jaringan namun dengan kondisi Kurang Baik.

Indikator Oranye : merupakan area cakupan koneksi sinyal dari pemancar bts dengan tingkat yang Tidak Baik.

Indikator Merah : memperlihatkan bahwa area cakupan tersebut sudah berada diluar frekuensi pemancar yang dihasilkan oleh bts, sehingga pengguna jasa layanan di area tersebut tidak bisa lagi menggunakan koneksi jaringan, karena dalam hal ini koneksi jaringan yang dihasilkan dalam keadaan Buruk.

Tabel 4 berikut akan memperlihatkan nilai masing-masing indikator berdasarkan lebar/luas daerah cakupannya.

Tabel 4. Indikator warna berdasarkan RSRP

\begin{tabular}{|c|c|}
\hline RSRP Criteria $(\mathrm{dBm})$ & Legend \\
\hline RSRP $>=-85$ & \\
\hline$-90<=\mathrm{RSRP}<-85$ & \\
\hline$-100<=\mathrm{RSRP}<-90$ & \\
\hline$-105<=\mathrm{RSRP}<-100$ & \\
\hline$-115<=\mathrm{DL}$ RSRP $<-105$ & \\
\hline RSRP $<-115$ & \\
\hline
\end{tabular}

Tabel 4 merupakan hasil pengukuran yang diperoleh dengan menggunakan PROBE dengan melihat krieria perngukuran berdasarkan RSRP. RSRP ( Reference
Signal Received Power ), merupakan kekuatan sinyal yang diterima oleh user dalam frekuensi tertentu. semakin jauh jarak antara site dan user, maka semakin kecil pula RSRP yang diterima oleh user.

\section{KESIMPULAN}

Adapun kesimpulan yang dapat diambil dari penelitian ini adalah :

1. Sebuah sinyal dapat dikatakan baik apabila kualitas dan kekuatannya mencapai target saat dilakukan pengukuran yaitu pada kondisi dimana RSRP $>=-85 \mathrm{dBm}$.

2. Dari hasil pengukuran terlihat indikator warna yang mewakili kualitas sinyal, dimana indikator biru tua merupakan kualitas sinyal yang paling baik sedangkan kualitas sinyal yang paling buruk ditandai dengan indikator warna merah.

3. Penyebab terjadinya Badspot (area cakupan yang buruk) yaitu adanya penghalang yang menyebabkan daya pancar antenna bts tidak maksimal, seperti gedung-gedung tinggi, pepohonan, dan sebagainya.

4. Parameter yang menetukan tingkat kualitas sinya antara lain adalah : RSRP, RSRQ, SINR, CQI, PCI

\section{DAFTAR PUSTAKA}

[1]. Arifwidodo, B. (2015). Optimasi dan Performansi Proses Rehoming Terhadap Teknologi Jaringan GSM, IncomTech, Jurnal Telekomunikasi dan Komputer, Vol.6, No.2.

[2] Santoso, G. (2016). Perkembangan Jaringan Komunikasi Wireless Menuju Teknologi 4G, Prosiding Seminar Nasional Aplikasi Sains \& Teknologi (SNAST), ISSN : 1979 - 911X, 
[3] Setiawan, N.W.A., Muayyadi, A.A., \& Vidyaningtyas, H. (2017). Optimasi Layanan Data Pada Jaringan LTE Dengan Genex Assistant Di Delanggu Kelaten, e-Proceeding of Engineering, ISSN : 2355-9365, Vol.4, No.3.

[4] Manual book, 2010, Mikrotik Router OS

[5] Wibowo, S.A., \& Z, A.J. (2013). Drive Test GSM Untuk Pengecekan Kelayakan Jaringan Pada PT. NEXWAVE Regional Jawa tengah Yogyakarta Devisi HCPT (3) Semarang. 